\title{
Testing the untestable: The CJEU's decision in Case C-473/16, $F$ v Bevándorlási és Állampolgársági Hivatal
}

Date:

Thursday, June 28, 2018

\section{Seeking refuge from homophobia}

Let's start with people. Because law should be about people, not (just) about abstract notions and fuzzy values. F - a Nigerian man - escaped Nigeria and reached Hungary, where he claimed international protection on the basis of his fear of persecution in his home country on grounds of his homosexuality. The authority dealing with F's claim - the Hungarian Immigration and Asylum Office - decided that to determine whether F was effectively gay, they needed to commission a psychological report. The report in question was based on projective personality tests, and concluded that it was not possible to corroborate the Applicant's self-declared sexual orientation. This was all the Hungarian authorities needed to feel entitled to deny the Applicant's claim. It is important to outline from the start four crucial aspects of this case: the report did not deny that the applicant was gay, but simply stated that it was not possible to prove it (if such a proof were at all possible); the Hungarian authorities did not find any fundamental contradiction in the Applicant's declarations; they did not consider the principle of the benefit of the doubt (as required by para. 203-204 of the UNHCR Handbook and Guidelines on Procedures and Criteria for Determining Refugee

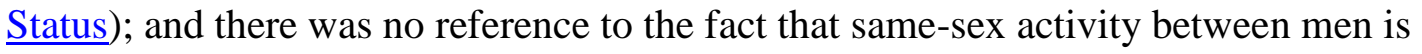
punishable in Nigeria with imprisonment of up to 14 years, or even the death penalty in the Northern Nigerian states that have adopted Sharia laws.

Against this background, F appealed against the negative decision of the Hungarian authorities, and the appeal court - the Administrative and Labour Court in Szeged - referred several questions to the Court of Justice of the European Union (CJEU). The key point referred to the application of Article 4 of Council Directive 2004/83/EC (on the assessment of facts and circumstances, in the meantime replaced by Directive 2011/95/EU). The CJEU was asked whether this norm, in the light of Article 1 of the Charter of Fundamental Rights of the European Union (EU Charter) protecting human dignity, precludes forensic psychologists' expert opinions based on projective personality tests from being used in asylum adjudication relating to LGBTI (lesbian, gay, bisexual, trans and intersex) claimants, even when such tests do not enquire about the applicants' sexual habits and do not entail a physical examination. Should that possibility be precluded, the referring Court also asked whether asylum authorities are prevented from examining by 'expert methods' the truthfulness of such international protection claims.

More specifically, the CJEU was called upon to assess the use of three types of projective drawing tests to assess sexuality, namely the 'Draw-a-Person-in-the-Rain' test, the Rorschach test and the Szondi test. These tests are used to obtain information from 'patients' where they struggle or prefer not to verbalise their feelings and experiences, in this way helping psychologists to assess personality, emotional well-being and mental health. As we have discussed in a previous blog post, even if these tools are still widely used by psychologists 
across the world, they are generally contentious and their use to assess an individual's sexuality has been utterly ruled out by the scientific community. As a consequence, neither the relevant literature nor reputable professionals make any use of such tests for these purposes, and the use of psychiatric and psychological evidence is generally ruled out in sexuality-related asylum cases, for example, in the UK. The fact that the Hungarian Institute of Forensic Experts and Investigators produced a report stating that such tests did not prejudice human dignity and were appropriate - along with a 'suitable exploration' of the issues - to indicate an individual's sexual orientation (see par. 25 of CJEU decision), is an indictment on the professional credibility of the individuals involved in producing the report. Yet, this was not the first time the CJEU has been confronted with highly dubious means of evidence in asylum cases involving sexuality.

\section{Worrying signs}

The CJEU has had three opportunities so far to deal with sexual orientation asylum claims. The first opportunity was in the joined cases $\underline{C}-199 / 12$ to C-201/12, X, Y and Z v. Minister voor Immigratie en Asiel, which positively outlawed the 'discretion requirement', in other words, the possibility of returning asylum claimants to their countries of origin on the basis that they can be 'discreet' about their sexual orientation. On a more negative note, however, the Court also determined that for the 'particular social group' ground of the 1951 Refugee Convention to be used in such cases, sexual orientation asylum applicants need to fulfil two tests: membership of a group socially recognisable in the country of origin (social recognition test) and recognition of sexual identity as a characteristic so fundamental to a person's identity that one should not have to renounce to it (fundamental characteristic test). The Court also determined that the criminalization of same-sex conduct does not in itself constitute an act of persecution. Both these points reflect a strict interpretation of EU law that runs against the UNHCR guidelines and commentators' views.

In the second sexual orientation asylum case brought before the CJEU, the Court deals more explicitly with evidentiary standards: in Joined Cases C-148/13 to C-150/13, A, B and C v Staatssecretaris van Veiligheid en Justitie, 2 December 2014, the CJEU asserted that the sexual orientation declared by asylum applicants 'constitute[s], having regard to the particular context in which the applications for asylum are made, merely the starting point in the process of assessment of the facts and circumstances', thus endorsing authorities' desire to subject asylum applicant's self-declared sexual orientation to close scrutiny. Although some European Union (EU) Member States circumvent that matter by generally accepting asylum applicants self-declared sexuality, many others are eager - like Hungary in the $F$ case - to closely scrutinise applicants' self-declared sexual orientation, disbelieve it wherever possible and thus find an easy route to deny the asylum claim. In $A, B$ and $C$, the Court appropriately refused the use of sexualised evidence or stereotyped assessments in sexual orientation asylum claims, thus precluding medical tests such as phallometric testing and explanation of sexual practices on the basis that the use of 'evidence' of this nature violates the dignity and privacy of the claimants (Articles 1 and 7 of the EU Charter). Yet, no positive guidance was offered as to what questions are appropriate in these circumstances. Moreover, questions based on stereotypes may still be asked, as part of overall balanced lines of questioning, thus still leaving much room for ambiguity and opening the door for inappropriate interviewing and decision-making.

The $F$ case brought the matter of sexual orientation asylum claims back into the EU arena and offered the Court an opportunity to improve some of the shortcomings of its two previous 
decisions on this type of claim. Whether or not the Court would use this opportunity effectively was far from obvious. Indeed, despite recognising that a psychologist cannot determine an applicant's sexual orientation based on personality tests, AG Wahl argued in his Opinion in this case that the tests in question should be admitted, provided that consent is obtained and the tests carried out in a way that is compatible with the rights to dignity and to respect for private and family life (Articles 1 and 7 of the EU Charter). AG Wahl effectively offered EU Member States an unreasonably wide margin of appreciation and an alarming scope to use 'fake science' to undermine asylum applicant's claims, which deserved our outright criticism. Would the Court do any better?

\section{Third time lucky indeed}

In its judgment, the CJEU went further than the AG Wahl's Opinion suggested and offered a much more cogent statement on the inappropriateness of using projective personality tests in

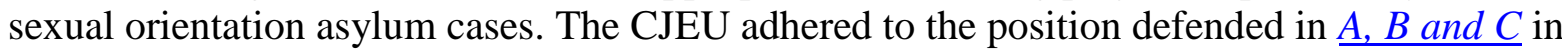
terms of applicants' statements being simply the starting point in the process of assessing the facts and circumstances of an international protection claim, which means that an applicant's self-identification as LGBTI may be subject to scrutiny as well (para. 28-29). Yet, the Court seems to have tried to offer a bolder position than in its previous decisions.

First, the Court highlights that, according to Article 10(2) of Directive 2011/95/EU, actually possessing the characteristic that allows an applicant to be considered a member of a particular social group (PSG) for the purposes of the international protection claim is, in fact, immaterial, as what matters is that such a characteristic be attributed to that applicant by the actor of persecution (par. 31). What is interesting in this is the emphasis the Court places on this point, which had not been explicitly raised by the referring Court or in the AG's Opinion and was not strictly relevant in this context. This is a welcome move by the Court, as it stressed that to establish a PSG the characteristic may simply be attributed to the person by the actor of persecution, and not necessarily be possessed by that person. This reading is in line with the spirit of the 1951 Convention and with UNHCR guidance, as provided in its Handbook (par. 66) and Guidelines No. 9 (para. 39 and 41). In the decision under comment, the Court referred to this point to argue that it is not always necessary to assess an applicant's sexual orientation when dealing with sexual orientation cases - as it would be the case when the non-heterosexual orientation is only perceived/attributed (par. 32). Hence, at the beginning of its reasoning, the Court seems to be sending the message that tests aiming to assess an applicant's sexual orientation are neither necessarily useful nor can they be used as a 'magic wand' to solve asylum cases.

Second, the Court accepts that Article 4(3) of Directive 2011/95/EU does not restrict the use of expert reports in the assessment of the facts and circumstances, but in line with the decision in $A, B$ and $C$, it also places special emphasis on respect for Article 1 (human dignity), Article 7 (right to respect for private and family life) and Article 47 (right to an effective remedy) of the EU Charter (para. 34-35 and 43). As the Court specifies, this requires that national authorities adapt their methods of assessment to each category of application, including the type of Country of Origin Information (COI) it produces or procures (para. 37-38). Crucially, and contradicting explicitly the position taken by the Hungarian referring court, this also requires national authorities to take ultimate responsibility for the individual assessment of facts and circumstances, rather than (dis)placing that burden on experts (para. 40-42). 
Third, the Court addressed head on the issue of consent. When commenting on the AG's Opinion in this case, we had argued that the CJEU would have to explain how applicants' genuine consent in such circumstances could be guaranteed, in the light of the inevitable pressure under which applicants must feel to undergo any tests deemed by national authorities as useful, even if not compulsory. We are very pleased to see that the Court has indeed questioned the genuinely free nature of consent from applicants under these circumstances (para. 52-53).

Fourth, in the light of the previous points, the Court considered that such tests constitute an unjustifiable and disproportionate interference with the Applicant's right to respect for private life and are thus precluded by EU law. This is the case especially owing to the lack of reliability of such tests, the particularly serious interference with private life they entail and their non-essential nature (para. 54-65). It is interesting that to strengthen its argumentation and similarly to the AG in his Opinion - the Court also relied on Principle 18 of the Yogyakarta Principles (protecting individuals from medical abuses based on sexual orientation or gender identity) (par. 62), which reinforces the legitimacy and legal authority of this tool in sexual orientation related litigation. The CJEU thus points out that national authorities would do better to focus on ensuring that asylum case workers have the necessary training and skills for themselves to assess all personal circumstances pertaining to each case, including sexual orientation matters (para. 66-67).

Importantly, in the light of Article 4(5) of Directive 2011/95/EU, the Court highlights that even in the absence of evidence, an applicant's statements regarding their sexuality may not need confirmation, especially if the applicant's statement is consistent and plausible (the provision in question also making reference to the applicant's 'genuine effort to substantiate his application', a 'satisfactory explanation ha[ving] been given regarding any lack of other relevant elements', the 'applicant ha[ving] applied for international protection at the earliest possible time', and 'the general credibility of the applicant ha[ving] been established') (par. 68). Although this still falls short of relying on applicants' sexual self-identification and makes no explicit reference to the principle of the benefit of the doubt (para. 203-204 of the UNHCR Handbook and Guidelines), such emphasis on an applicant's overall credibility reflects a genuine and positive effort from the CJEU to promote fair and lawful asylum decision-making procedures at the hands of national authorities.

\section{A light at the end of the tunnel?}

In a nutshell, the Court's message is that it is acceptable for national authorities to commission expert reports in asylum cases related to sexual orientation, but the tests in question in the $F$ case should be precluded. The overall tone of the decision is - we argue more positive towards asylum seekers persecuted on grounds of their sexual orientation than past decisions of the CJEU have been. One could thus be tempted to think that the idiom 'third time lucky' applies here. We share that positive reading of this judgment. Yet, we would also like to point out that, once more, the Court did not offer any positive guidance as to how authorities should deal with evidentiary standards in this context and failed to recognise the importance of self-declared sexual orientation. At the same time, it must be noted that the CJEU preliminary rulings function through requests referred by domestic courts and the CJEU is thus bound by the questions asked by the referring court (although the Court has taken, in certain instances, a more proactive approach: see, e.g. Abdida). Therefore, one way to instigate greater clarity is for domestic courts to shape the questions they refer to the CJEU in a way that allows the Luxembourg judges to actually give positive guidance. On 
another note, the current CJEU jurisprudence on sexual orientation asylum cases and its related future jurisprudence have the effect of drawing clear lines between what does and what does not respect human rights. This is to say that, little by little, article by article of the EU Charter, the CJEU is indeed shaping the boundaries of sexual orientation asylum cases in the EU asylum acquis.

The best way forward to improve the way sexual orientation asylum claims are decided seems to entail the combination of a series of legislative amendments with a three-pronged non-legislative strategy: training, guidance and quality control. First, much better training needs to be offered to decision-makers who deal with sexual orientation asylum claims. Only appropriately qualified decision-makers who benefit from high-quality training in the field of gender and sexuality will be able to deconstruct and resist stereotyped and Euro/Westerncentric views of how a credible asylum claimant should present their story involving persecution on grounds of sexual orientation, and what means of evidence are appropriate in such instances. As for the training, given that the topic is indeed complex and requires a high level of expertise, the focus should not be on its quantity and content (although regular, comprehensive and multidisciplinary training is undoubtedly useful), but rather, perhaps, on methodologies and means of training. In particular, we believe that training on sexual orientation and gender identity asylum claims would benefit from the input of refugee and LGBTQI+ groups more familiar with the issues in question. Moreover, the participation of LGBTQI+ refugees in training curricula could be envisaged at different stages, such as in designing such training courses. Listening to the voices of yesterday's refugees can help us address more effectively the needs of today's refugees. Second, comprehensive, effective and readily available guidance needs to be produced and disseminated, as to reach all domestic authorities dealing with sexual orientation cases. Key principles and positive guidance (but not prescriptive lists of questions) need to be established covering what aspects should be discussed, how such interviews should be conducted, and what means of evidence a decisionmaker should use. Finally, a reliable and impartial quality control system needs to be put in place, to allow the quick identification of inappropriate evidentiary practices and introduction of improvements. In short, much work still needs to be carried out by domestic asylum authorities, that at an institutional and individual level, consciously or unconsciously, still resist improvements and perpetuate harmful practices. An arduous, but essential body of work lies ahead.

Nuno Ferreira, University of Sussex

Professor of Law, SOGICA's project leader

Denise Venturi, Scuola Superiore Sant'Anna and KU Leuven

$\mathrm{PhD}$ Student in International Law and Human Rights

The authors wish to thank the useful comments provided by Carmelo Danisi, Moira Dustin and Nina Held on previous drafts of this text. 
The views expressed herein are those of the authors and do not necessarily reflect the views of the United Nations, ECRE or EDAL. 